\title{
PENINGKATAN KETERAMPILAN PROSES DAN HASIL BELAJAR SUBTEMA TUGASKU SEHARI-HARI DI RUMAH MENGGUNAKAN MODEL PEMBELAJARAN SAVI PADA SISWA KELAS II SDN 1 BOLO
}

\author{
Eka Ning Tyas \\ ekaningtyas99@gmail.com \\ SD Negeri 1 Bolo - Wonosegoro - Boyolali
}

\begin{abstract}
ABSTRAK
Tujuan penelitian ini adalah untuk meningkatkan keterampilan proses dan hasil belajar siswa menggunakan model pembelajara SAVI (Somatik, Auditori, Visual, Intelektual) pada sub tema tugasku sehari-hari di rumah. Jenis penelitian yang digunakan dalam penelitian ini adalah penelitian tindakan kelas, yang terdiri dari dua siklus. Masing-masing siklus terdiri atas tahapan perencanaan tindakan, pelaksanaan tindakan, observasi, dan refleksi. Instrumen pengumpulan data menggunakan penilaian rubrik keterampilan proses dalam melakukan pengamatan proses perbaikan pembelajaran, dan untuk mengukur hasil belajar muatan Bahasa Indonesia dan Matematika dengan menggunakan soal tes. Analisis data dilakukan menggunakan analisis deskriptif komparatif yaitu membandingkan kondisi awal, hasil siklus 1, dan hasil siklus 2. Hasil penelitian menunjukkan temuan bahwa model pembelajaran SAVI: a) meningkakan keterampilan proses pembelajaran sub tema Tugasku sehari-hari siswa kelas II SD Negeri 1 Bolo, Wonosegoro-Boyolali Persentase kenaikan keterampilan proses pembelajaran sebesar 22,96\% pada siklus 1 dan pada siklus 2 sebesar 21,22\%. b) Meningkatkan persentase jumlah hasil belajar siswa yang mencapai KKM muatan Bahasa Indonesia pada kondisi awal 31,82\% (7 Siswa), Siklus 1 meningkat menjadi 50\% (11 siswa), dan siklus 2 menjadi 86,36\% (19 Siswa). Hasil belajar muatan Matematika pada kondisi awal 27,27\% (6 Siswa), meningkat menjadi 45,45\% (10 Siswa) pada siklus 1 dan meningkat menjadi $81,82 \%$ (18 Siswa) siklus 2.
\end{abstract}

Kata kunci : Keterampilan proses, hasil belajar, model pembelajaran SAVI.

\section{PENDAHULUAN}

Lampiran Permendikbud No. 65 Tahun 2013 tentang standar proses pendidikan menerangkan bahwa, Pendidikan merupakan usaha sadar dan terencana untuk mewujudkan suasana belajar dan proses pembelajaran agar peserta didik secara aktif mengembangkan potensi dirinya untuk memiliki kekuatan spiritual, pengendalian diri, kepribadian, kecerdasan akhlak mulia, keterampilan yang diperlukan 
dirinya, masyarakat, bangsa, dan negara.

Proses pembelajaran pada satuan pendidikan diselenggarakan secara interaktif, inspiratif, menyenangkan, menantang, memotivasi peserta didik untuk berpartisipasi aktif, serta memberikan ruang yang cukup bagi prakarsa, kreativitas, dan kemandirian sesuai dengan bakat, minat, dan perkembangan fisik serta psikologis peserta didik.

Berdasarkan hal tersebut, terdapat dua hal yang perlu diperhatikan dalam dunia pendidikan. Pertama, adanya tuntutan penyelenggaraan pembelajaran secara menyenangkan. Kedua, pendidikan hendaknya dikembangkan selaras dengan minat siswa. Perwujudan kedua hal tersebut, siswa diharapkan akan memiliki kreativitas dan kemandirian, sebagai salah satu tujuan pembelajaran di Indonesia, sehingga keberhasilan pembelajaran akan meningkat. Oleh karena itu, diperlukan upaya untuk menciptakan proses pembelajaran secara interaktif dan menyenangkan bagi siswa.

Keberhasilan pembelajaran dalam arti tercapainya standar kompetensi sangat tergantung pada kemampuan guru mengolah pembelajaran yang dapat menciptakan situasi yang memungkinkan siswa belajar sehingga merupakan titik awal berhasilnya pembelajaran.

Namun pada kenyataannya di SDN 1 Bolo guru belum mampu me- ngolah pembelajaran, model yang digunakan masih kontekstual atau ceramah, pembelajaran hanya berpusat pada guru, siswa hanya mendengarkan saja dan guru lebih mendominasi pembelajaran, hal ini berpengaruh terhadap rendahnya tingkat keterampilan proses dan hasil belajar siswa.

Data hasil pengamatan awal terhadap proses pembelajaran pada sub tema bermain di lingkungan rumah, menunjukkan keterampilan proses mengamati, menanya, mencoba, mengumpulkan informasi, mengasosiasi, mengkomunikasi masih sangat rendah ratarata hanya 11,50 dan skor maksimal hanya 15 dari skor maksimal 24.

Rendahnya keterampilan proses pembelajaran tersebut berdampak pada hasil belajar siswa. Data awal pembelajaran pada sub tema bermain di lingkungan rumah tingkat kompetensi hasil belajar siswa dengan KKM 67 ternyata kondisi awal pada muatan Bahasa Indonesia hanya ada 7 siswa $(31,82 \%)$ dari 22 siswa yang telah mencapai KKM. Sedangkan pada muatan Matematika hanya ada 6 dari 22 siswa $(27,27 \%)$ yang telah mencapai KKM.

Hosnan (2014:208) mengemukakan ada model-model pembelajaran yang dapat melibatkan peserta didk secara aktif, sehingga pembelajaran lebih menyenangkan, dan materi yang disampaikan mudah dimengerti. Model pembelajaran SAVI salah satu model alternatif yang dapat melibatkan siswa 
Peningkatan Keterampilan Proses dan Hasil Belajar Subtema Tugasku Sehari-hari di Rumah (Eka Ning Tyas)

secara aktif dan menyenangkan melalui panca indra sehingga meningkatkan keterampilan proses dan hasil belajar.

Berdasarkan latar belakang masalah di atas, maka peneliti perlu untuk memperbaiki keterampilan proses dan hasil belajar tersebut melalui model pembelajaran SAVI, dengan tujuan untuk meningkatkan keterampilan proses pembelajaran, meningkatkan hasil belajar siswa, dan mencari cara yang paling efektif dalam pembelajaran pada subtema tugasku sehari-hari di rumah pada siswa kelas II SD Negeri 1 Bolo Kecamatan Wonosegoro, Kabupaten Boyolali.

\section{KAJIAN PUSTAKA}

Pada kurikulum 2013 semua kelas pada sekolah dasar menggunakan pendekatan tematik terpadu (PTP), atau tematik integratif. Penerapan model PTP tidak meninggalkan model dan metode pembelajaran yang lain. PTP merupakan model payung. Strategi pembelajaran lain yang bertujuan untuk meningkatkan kecakapan tertentu tetap dilaksanakan dengan PTP.

Pembelajaran Tematik Terpadu memiliki perbedaan kualitatif dengan model pembelajaran lain. PTP sifatnya memandu peserta didik mencapai kemampuan berfikir tingkat tinggi atau keterampilan berpikir dengan mengoptimalisasi kecerdasan ganda, sebuah proses inovatif bagi pengembangan dimensi sikap, ketrampilan dan pengetahuan.
Dalam pembelajaran tematik, tema berperan sebagai pemersatu kegiatan pembelajaran dengan memadukan beberapa pelajaran sekaligus. Adapun muatan pelajaran yang dikembangkan adalah muatan pelajaran PPKn, Bahasa Indonesia, IPS, IPA, Matematika, Seni Budaya dan Prakarya, serta Pendidikan Jasmani Olahraga dan Kesehatan. Dalam kurikulum 2013, tema sudah disiapkan oleh pemerintah dan dikembangkan menjadi sub tema dan satuan pembelajaran.

Dalam Materi Pelatihan Guru Implementasi Kurikulum 2013 (Kemdikbud, 2014) juga disebutkan fungsi dari Pembelajaran Tematik Terpadu adalah untuk memberikan kemudahan bagi peserta didik dalam memahami dan mendalami konsep materi yang tergabung dalam tema serta dapat menambah semangat belajar karena materi yang dipelajari merupakan materi nyata (kontekstual) dan bermakna bagi peserta didik.

Adapun tujuan pembelajaran dalam tematik terpadu antara lain: Mudah memusatkan perhatian pada satu tema atau topik tertentu, mempelajari pengetahuan dan mengembangkan berbagai kompetensi muatan pelajaran dalam tema yang sama, memiliki pemahaman terhadap materi pelajaran lebih mendalam dan berkesan, mengembangkan kompetensi berbahasa lebih baik dengan mengaitkan berbagai muatan pelajaran lain dengan pengalaman pribadi peserta 
didik, lebih bergairah belajar karena mereka dapat berkomunikasi pada situasi nyata, seperti bercerita, bertanya, menuis sekaligus mempelajari pelajaran yang lain, lebih merasakan manfaat dan makna belajar karena materi yang disajikan dalam konteks tema yang jelas, guru dapat menghemat waktu, karena mata pelajaran yang disajikan secara terpadu dapat dipersiapkan sekaligus dan diberikan dalam 2 atau 3 pertemuan bahkan lebih, dan budi pekerti dan moral peserta didik dapat ditumbuh kembangkan dengan mengangkat sejumlah nilai budi pekerti sesuai dengan situasi dan kondisi.

Menurut permendikbud 2013, pembelajaran tematik integratif merupakan pembelajaran yang menggunakan pendekatan saintifik untuk mengukur keterampilan proses. Dalam penelitian ini pendekatan saintifik yang diintegrasikan dengan model pembelajaran SAVI dengan keterampilan proses.

Hosnan (2014:34) mengemukakan bahwa implementasi kurikulum 2013 dalam pembelajaran dengan pendekatan saintifik adalah proses pembelajaran yang dirancang sedemikian rupa agar peserta didik secara aktif mengonstruk konsep, hukum atau prinsip melalui tahapan-tahapan mengamati, merumuskan masalah, mengajukan atau merumuskan hipotesis, mengumpulkan data dengan berbagai tehnik, menganalisis data, menarik kesimpulan dan mengkomunikasikan konsep, hukum atau prinsip yang "ditemukan". Kondisi pembelajaran yang diharapkan dari pendekatan saintifik adalah mendorong peserta didik dalam mencari tahu dari berbagai sumber melalui observasi, bukan hanya diberi tahu.

Dengan menggunakan pendekatan saintifik yang diintegrasikan dengan model pembelajaran SAVI maka pembelajaran akan menyenangkan. Dengan pembelajaran yang menyenangkan maka diharapkan dapat meningkatkan keterampilan proses dan hasil belajar siswa.

Hasil belajar merupakan tujuan akhir dilaksanakannya kegiatan pembelajaran di sekolah. Hasil belajar dapat ditingkatkan melalui usaha sadar yang dilakukan secara sistematis mengarah kepada perubahan positif yang kemudian disebut dengan proses belajar. Akhir dari proses belajar merupakan perolehan hasil belajar siswa. semua hasil belajar tersebut merupakan hasil dari suatu interaksi tindak belajar dan tindak mengajar. Dari sisi guru tindak mengajar diakhiri dengan proses evaluasi hasil belajar. Sedang dari sisi siswa, hasil belajar merupakan puncak proses belajar (Dimyati dan Mujiono, 2009:3).

Menurut Sudjana (2010:22), hasil belajar merupakan kemampuan yang dimiliki siswa setelah menerima pengalaman belajar. Kemudian Wahid murni, Arrifin mustikawan, dan Ali Ridho (2010:18) mengemukakan bah- 
Peningkatan Keterampilan Proses dan Hasil Belajar Subtema Tugasku Sehari-hari di Rumah (Eka Ning Tyas)

wa seorang dikatakann berhasil dalam belajar jika ia mampu menunjukkan perubahan dalam dirinya. Baik dari segi kemampuan berfikirnya, keterampilannya, atau sikapnya terhadap suatu objek.

Hasil belajar dapat tertuang dalam taksonomi Bloom dikelompokkan dalam tiga ranah (domain) yaitu berpikir (kognitif), sikap (afektif), keterampilan (psikomotor).

Sehubungan dengan itu, Gagne (dalam Sudjana, 2010:22) mengembangkan kemampuan hasil belajar menjadi lima, antara lain hasil belajar intelektual merupakan hasil belajar terpenting dari sistem lingsikolastik, strategi kognitif mengatur cara belajar dan berpikir seseorang termasuk kemampuan memecahkan masalah, sikap dan nilai intensitas emosional yang dimiliki seseorang, informasi verbal pengetahuan dalam arti informasi dan fakta, dan keterampilan motorik berfungsi untuk lingkungan hidup serta memprestasikan konsep dan lambang.

Dari beberapa pendapat tentang hasil belajar dapat disimpulkan bahwa hasil belajar merupakan hasil akhir dari proses kegiatan belajar siswa dari seluruh kegiatan siswa dalam mengikuti pembelajaran dikelas, menerima suatu pelajaran untuk men-capai kompetensi yang akan dicapai dengan menggunakan alat penilaian yang di susun guru berupa tes yang ha-silnya adalah nilai kemampuan sisiwa setelah tes diberikan sebagai per-wujudan dari upaya yang telah dila-kukan selama proses belajar mengajar. Hasil belajar siswa dihitung berda-sarkan evaluasi, pengukuran, dan assesment.

Menurut Wahid Murni, Arrifin Mustikawan, dan Ali Ridho (2010:15) ada tujuh tujuan penilaian, yaitu untuk mengetahui tingkat penguasaan peserta didik terhadap ma-teri yang telah diberikan, untuk mengetahui kecakapan, motivasi, bakat, minat dan sikap peserta didik terhadap program pembelajaran, untuk menge-tahui tingkat kemajuan dan kesesuaian hasil belajar peserta didik dengan standar kompetensi dan kompetensi dasar yang telah ditetapkan, untuk mendiag-nosis keunggulan dan kelemahan peserta didik dalam mengikuti kegiatan pembelajaran, untuk seleksi yaitu untuk memilih dan menentukan peserta didik yang sesuai dengan jenis pendidikan tertentu, untuk menentukan kenaikan kelas, untuk menempatkan peserta didik sesuai dengan potensi yang dimilikinya.

Dari uraian di atas, dapat disimpulkan bahwa hasil belajar sangat bergantung dari proses pembelajaran itu sendiri. Proses pembelajaran yang bermakna, dan menyenangkan akan sangat berpengaruh pada hasil belajar siswa. SAVI merupakan salah satu model pembelajaran alternatif yang dapat melibatkan siswa secara aktif dan menyenangkan melalui panca indera sehingga meningkatkan kete- 
rampilan proses dan hasil belajar. Berikut uraian secara mendalam tentang pembelajaran SAVI.

Pembelajaran SAVI merupakan pembelajaran yang menekankan bahwa belajar haruslah memanfaatkan semua alat indra yang dimiliki peserta didik. Pembelajaran SAVI menganut aliran ilmu kognitif modern yang menyatakan belajar yang paling baik adalah melibatkan emosi, seluruh tubuh, semua indra dan segenap kedalaman serta keluasan pribadi, menghormati gaya belajar individu lain dengan menyadari bahwa orang belajar dengan cara yang berbeda.

Meier (2002:91) menyatakan bahwa SAVI merupakan suatu model pembelajaran dengan cara menggabungkan gerakan fisik dengan aktivitas, intelektual, dan penggunaan semua alat indra. Unsur-unsur yang terdapat da-lam SAVI antara lain: Somatik berasal dari bahasa Yunani yang berarti tubuh. Belajar somatis berarti belajar dengan indra peraba, kinetesis, praktis melibat-kan fisik dan menggunakan tubuh sewaktu belajar secara berkala. Meier juga menguatkan pendapatnya dengan menyampaikan hasil penelitian neuro-logis yang menemukan bahwa pikiran tersebut di seluruh tubuh. Jadi dari temuan tersebut dapat disimpulkan bahwa dengan menghalangi pembe-lajar somatis menggunakan tubuh me-reka sepenuhnya.
Somatik berarti bangkit dari tempat duduk dan bertindak aktif secara fisik selama proses belajar. Berdiri dan bergerak kesana kemari meningkatkan sirkulasi dalam tubuh dan oleh karena itu mendatangkan energi segar ke dalam otak. Belajar somatis merupakan belajar dengan indra peraba, kinestetis, praktis dengan melibatkan fisik dan menggunakan serta menggerakkan tubuh sewaktu belajar. Belajar somatis ini bisa terhadap tubuh dimana anak-anak yang bersifat somatis, yang tidak dapat duduk tenang dan harus menggerakkan tubuh mereka untuk membuat pikiran mereka tetap hidup. Dalam belajar somatis ini tubuh dan pikiran itu satu dimana penelitian neurologis telah menemukan bahwa pikiran tersebar diseluruh tubuh. Tubuh adalah pikiran dan pikiran adalah tubuh. Jadi dengan menghalangi pembelajar somatis menggunakan tubuh dalam belajar maka menghalangi fungsi pikiran sepenuhnya. Melibatkan tubuh, untuk merangsang hubungan pikiran dan tubuh maka harus tercipta suasana belajar yang dapat membuat orang bangkit dan berdiri dari tempat duduk dan aktif secara fisik dari waktu ke waktu.

Auditori, pikiran auditori lebih kuat dari apa yang di sadari. Telinga bekerja terus menerus menangkap dan menyimpan informasi auditori. Dan ketika membuat suara sendiri dengan berbicara, maka beberapa area penting di otak pun menjadi aktif. Dalam me- 
Peningkatan Keterampilan Proses dan Hasil Belajar Subtema Tugasku Sehari-hari di Rumah (Eka Ning Tyas)

rancang pelajaran yang menarik bagi saluran auditori yang kuat dalam diri pembelajar, maka dengan cara mendorong pembelajar untuk mengungkapkan dengan suara. Pembelajaran auditori merupakan belajar paling baik jika mendengar dan mengungkapkan katakata.

Menurut Meier (2004: 95), belajar Auditori merupakan cara belajar standar bagi semua orang sejak awal sejarah. Seperti kita ketahui sebelum manusia mengenal baca tulis banyak informasi yang disampaikan dari generasi ke generasi secara lisan misalnya mitos, dongeng-dongeng, ceritacerita rakyat. Bangsa yunani kuno juga mendorong orang untuk belajar dengan suara lantang melalui dialog. Filosofi mereka adalah "jika kita mau belajar lebih banyak tentang apa saja, bicaralah tanpa henti”.

Visual, Ketajaman penglihatan setiap orang itu kuat, disebabkan oleh fikiran manusia lebih merupakan prosesor citra dari prosesor kata. Citra karena konkret mudah untuk diingat dan kata, karena abstrak sehingga sulit untuk disimpan. Didalam otak terdapat lebih banyak perangkat untuk memproses informasi visual daripada semua indra yang lain. Pembelajar visual belajar paling baik jika dapat melihat contoh dari dunia nyata, diagram, peta gagasan, ikon, gambar dan gambaran dari segala macam hal ketika sedang belajar. Dengan membuat yang visual paling tidak sejajar dengan yang verbal sehingga dapat membantu pebelajar untuk belajar lebih cepat dan baik.

Menurut Meier (2004: 97), setiap orang memiliki ketajaman visual yang sangat kuat. Hal ini dikarenakan didalam otak terdapat lebih banyak perangkat untuk memproses informasi visual dari pada semua indra yang lainnya. Lebih lanjut meier mengungkapkan bahwa beberapa siswa (terutama pembelajar visual) akan lebih mudah belajar jika dapat melihat apa yang dibicarakan guru atau sebuah buku.

Intelektual merupakan bagian diri yang merenung, mencipta, memecahkan masalah dan membangun makna. Intelektual adalah pencipta makna dalam pikiran, sarana yang digunakan manusia untulk berfikir, meyatukan pengalaman, menciptakan jaringan saraf baru dan belajar. Pada intelektual identik dengan melibatkan pikiran untuk menciptakan pembelajarannya sendiri. Belajar bukanlah menyimpan informasi tetapi menciptakan makna, pengetahuan dan nilai yang dapat dipraktekkan oleh pikiran pebelajar.

Menurut Meier (2004:99), kata intelektual menunjukkan apa yang dilakukan siswa dalam pikirannya secara internal ketika mereka menggunakan kecerdasan mereka untuk merenungkan suatu pengalaman dan menciptakan hubungan makna, rencana dan nilai dari pengalaman tersebut. Lebih lanjut meier mendefinisikan intelektual sebagai pencipta makna dalam pikiran, 
sarana yang digunakan manusia untk berfikir, menyatukan pengalaman, menghubungkan pengalaman mental, fisik, emosional dan unuititif tubuh untuk membat makna baru bagian dirinya sendiri.

Menurut Warta (2010:40), "model pembelajaran SAVI merupakan suatu model pembelajaran yang menekankan bahwa belajar haruslah memanfaatkan semua alat indera yang dimiliki oleh siswa". Dari pengertian ini, jelas bahwa model SAVI merupakan suatu model pembelajaran yang menggabungkan gerak fisik dengan aktivitas intelektual dan penggunaan semua inderanya dalam proses pembelajaran.

Meier (Sidjabat, 2009) mengajukan sejumlah prinsip pokok dalam belajar dengan menggunakan model SAVI, yaitu pembelajaran melibatkan seluruh pikiran dan tubuh, pembelajaran berarti berkreasi bukan mengkonsumsi, kerjasama membantu proses pembelajaran, pembelajaran berlangsung pada banyak tingkatan secara simultan, belajar berasal dari mengerjakan pekerjaan itu sendiri dengan umpan balik, emosi positif sangat membantu pembelajaran, otak citra menyerap informasi secara langsung dan otomatis.

Jadi pada dasarnya pembelajaran SAVI ini lebih menonjolkan bagaimana siswa menciptakan kreatifitasnya sendiri. Hal ini akan berpengaruh pada cara berpikir siswa men- jadi lebih terbuka dan mencoba untuk menggali kemampuannya dalam memperoleh kemampuan yang baru.

Namun dalam pembelajaran dengan model $S A V I$ selain memiliki kelebihan juga memiliki kelemahan. Kelebihan model SAVI diantaranya membangkitkan kecerdasan terpadu siswa secara penuh melalui penggabungan gerak fisik dengan aktivitas intelektual, Siswa tidak mudah lupa karena siswa membangun sendiri pengetahuannya, suasana dalam proses pembelajaran menyenangkan karena siswa merasa diperhatikan sehingga siswa tidak cepat bosan untuk belajar, memupuk kerjasama karena siswa yang lebih pandai diharapkan dapat membantu yang kurang pandai, memunculkan suasana belajar yang lebih baik, menarik dan efektif, mampu membangkitkan kreatifitas dan meningkatkan kemampuan psikomotor siswa, memaksimalkan ketajaman konsentrasi siswa, siswa akan lebih termotivasi untuk belajar lebih baik, melatih siswa untuk terbiasa berpikir dan mengemukakan pendapat dan berani menjelaskan jawabannya, merupakan variasi yang cocok untuk semua gaya belajar.

Sedangkan kelemahan dalam model pembelajara $S A V I$ antara lain model ini menuntut adanya guru yang sempurna sehingga dapat memadukan keempat komponen dalam SAVI secara utuh, penerapan model ini membutuhkan kelengkapan sarana dan prasarana 
Peningkatan Keterampilan Proses dan Hasil Belajar Subtema Tugasku Sehari-hari di Rumah (Eka Ning Tyas)

pembelajaran yang menyeluruh dan disesuaikan dengan kebutuhannya, sehingga memerlukan biaya pendidikan yang sangat besar. Terutama untuk pengadaan media pembelajaran yang canggih dan menarik. Ini dapat terpenuhi pada sekolah-sekolah maju. (Meier, 2005:91-99) dalam http:// goez 17.wordpress.com), karena siswa terbiasa diberi informasi terlebih dahulu sehingga siswa kesulitan dalam menemukan jawaban ataupun gagasannya sendiri, membutuhkan waktu yang lama terutama bila siswa yang lemah, membutuhkan perubahan agar sesuai dengan situasi pembelajaran saat itu, belum ada pedoman penilaian, sehingga guru merasa kesulitan dalam evaluasi atau memberi nilai, model SAVI masih tergolong baru, sehingga banyak pengajar guru yang belum mengetahui model SAVI tersebut, model SAVI ini cenderung kepada keaktifan siswa, sehingga untuk siswa yang memiliki tingkat kecerdasan kurang, menjadikan siswa itu minder.

Sintak Model Pembelajaran SAVI merupakan suatu perencanaan atau suatu pola yang digunakan sebagai pedoman dalam merencanakan pembelajaran di kelas atau dalam tutorial. Model pembelajaran mengacu pada pendekatan pembelajaran yang akan digunakan termasuk didalamnya tujuan pembelajaran, tahap dalam kegiatan pembelajaran, lingkungan pembelajaran dan pengelolaan kelas.
Sintak Model Pembelajaran SAVI melalui beberapa tahap. Adapun tahapan-tahapan itu meliputi 1. Membangkitkan minat siswa, memberikan perasaan positif mengenai pengalaman belajar yang akan datang, dan menempatkan mereka dalamsituasi optimal untuk belajar, 2. Membantu siswa menemukan materi belajar yang baru dengan cara menarik, menyenangkan, relevan, melibatkan panca indra,dan cocok untuk semua gaya belajar, 3 . Mengintegrasikan dan menyerap pengetahuan dan keterampilan baru dengan berbagai cara, 4. Membantu siswa menerapkan dan memperluas pengetahuan atau keterampilan baru mereka pada pekerjaan sehingga hasil belajar akan terus meningkat.

Suasana belajar dikatakan baik apabila didukung dengan keadaan yang positif dan adanya minat dalam diri pembelajar sehingga dapat mengoptimalkan pembelajaran. Menurut Dave Meier (2002:33-34) ada beberapa alasan yang melandasi perlunya diterapkan model SAVI dalam kegiatan belajar sehari-hari khususnya pada tugasku sehari-hari yaitu dapat terciptanya lingkungan yang positif, keterlibatan pembelajar sepenuhnya, adanya kerjasama diantara pembelajar, menggunakan metode yang bervariasi tergantung dari pokok bahasan yang dipelajari, dapat menggunakan belajar kontekstual, dapat menggunakan alat peraga 
Belajar bisa menjadi optimal jika keempat unsur SAVI ada dalam suatu peristiwa pembelajaran. Pembelajaran pada tema tugasku sehari-hari dengan model SAVI yaitu cara belajar yang melibatkan seluruh indra, belajar dengan bergerak aktif secar fisik dan membuat seluruh tubuh atau pikiran ikut terlibat dalam proses belajar. Unsur-unsur pendekatan safi adalah belajar sumstic, Auditori, Visual, dan intelektual. Tindakan guru yang dilakukan dalam meningkatkan aktifitas dan hasil belajar siswa dalam pembelajaran tugasku sehari-hari melalui model pembelajaran SAVI merupakan penyatuan keempat unsur SAVI dalam satu pembelajaran pada tema Tugasku sehari-hari.

Berdasarkan hakikat pembelajaran tematik terpadu, keterampilan proses pendekatan saintifik, dan hasil belajar seperti yang telah diuraikan di atas, maka model pembelajaran SAVI dapat dijadikan salah satu alternatif model pembelajara tematik di SD. Implementasi model pembelajaran SAVI secara teoritik dapat meningkatkan kompetensi keterampilan proses dan hasil belajar siswa. Berbagai penelitian tindakan membuktikan potensi SAVI tersebut secara empirik. Johar Wahyudi, Cicillia Novi Primiani, Yayuk wahyuni (2011) menemukan bahwa model SAVI dapat meningkatkan kemampuan berfikir tingkat tinggi pada mata pelajaran Biologi. Sri Wahyuni Kusumawati (2013) meneliti tentang penerapan model pembelajar SAVI untuk meningkatkan keterampilan pemecahan masalah di Sekolah Dasar. Suswadi (2010) tentang peningkatan keterampilan membaca pemahaman dengan pendekatan SAVI pada siswa kelas VI SDN Kutawaru 04 Kecamatan silacap tengah Kabupaten Cilacap. Purwanti Silvianawati, 2012 melakukan PTK dan menemukan hasil model pembelajaran SAVI berpengaruh terhadap hasil belajar pada pembelajaran tematik pada tema hewan dan tumbuhan kelas II SD Negeri Mangunsari 04 Salatiga. Krisnawati, Ony. 2011 melakukan PTK dan menyimpulkan bahwa hasil penerapan model SAVI dapat mengubah miskonsepsi siswa, meningkatkan aktivitas dan hasil belajar siswa pada siswa kelas IV SDN Talangagung 01 Kecamatan Panjen Kabupaten Malang.

Uraian tentang hakikat pembelajaran SAVI dan temuan berbagai penelitian di atas berimplikasi pada desain model pembelajaran dan penelitian pembelajaran. Model pembelajaran merupakan penunjang guru dalam proses pembelajaran, agar proses pembelajarannya berjalan dengan baik dan diterima baik oleh siswa. Oleh karena itu, guru harus betul-betul memperhatikan dan harus kreatif dalam memilih model pembelajaran yang sesuai dengan karakteristik siswa.

Mencermati uraian tentang sintak SAVI di atas, sebenarnya dapat disepadankan dengan keterampilan 
Peningkatan Keterampilan Proses dan Hasil Belajar Subtema Tugasku Sehari-hari di Rumah (Eka Ning Tyas)

proses ilmiah dalam pendekatan saintifik. Langkah membangkitkan minat siswa, memberikan perasaan positif mengenai pengalaman belajar yang akan datang, dan menempatkan mereka dalam situasi optimal untuk belajar dilakukan dengan cara mengamati dalam pembelajaran. Mnemukan materi belajar baru dengan cara menarik, menyenangkan, relevan, dan cocok untuk semua gaya belajar sejalan dengan aktivitas mengamati, mennanya, mencoba, mengumpulkan informasi, mengasosiasi, dan mengkomunikasikan. Kegiatan pembelajaran dengan mengintegrasikan, menyerap pengetahuan dan keterampilan baru dengan berbagai cara dalam sintak SAVI juga relevan dengan mengumpulkan informasi dan mengasosiasikan. Kegiatan siswa menerapkan dan memperluas pengetahuan atau keterampilan baru mereka pada pekerjaan sehingga belajar akan terus meningkat merupakan kegiatan yang relevan dengan kegiatan mengumpulkan informasi dan mengkomunikasikan dalam pendekatan saintifik.

Berdasarkan uraian di atas dalam pembelajaran pada subtema tugasku sehari-hari di rumah, bisa ditangkap bahwa dalam proses pembelajaran perlu dipilih model pembelajaran yang tepat agar dapat membangkitkan keaktifan dan meningkatkan hasil belajar siswa. Dengan memilih model pembelajaran SAVI dalam proses pembelajaran maka diduga dapat meningkatkan keaktifan dan hasil belajar siswa pada sub tema tugasku sehari-hari di rumah.

\section{METODE PENELITIAN}

PTK dilakukan di SDN 1 Bolo Kecamatan Wonosegoro, Kabupaten Boyolali semester 1 tahun pelajaran 2014/2015, pada Subtema tugasku sehari-hari di rumah Subyek yang dilibatkan dalam penelitian ini adalah siswa kelas II dengan jumlah siswa dalam satu kelas 22 orang, 6 siswa perempuan, dan 16 Siswa laki-laki.

Variabel yang diteliti dalam penelitian tindakan kelas ini adalah Variabel tindakan dalam proses pembelajaran (variabel $\mathrm{X}$ ): implementasi model pembelajaran SAVI pada sub tema tugasku sehari-hari di rumah. Variabel Y: Peningkatan keterampilan proses dan hasil belajar siswa.

Teknik pengumpulan data dilakukan dengan observasi untuk mengumpulkan data aktivitas guru dan siswa. Tes, untuk mengukur kompetensi hasil belajar siswa untuk seluruh muatan pembelajaran. Non tes berupa rubrik penilaian keterampiilan proses untuk mengukur keterampilan proses dalam pembelajaran. Sebagai tolak ukur keberhasilan dalam Penelitian Tindakan Kelas ini ditetapkan indikator kinerja sebagai berikut: 1) Pembelajaran dikatakan berhasil jika Presentase jumlah siswa yang mencapai KKM sebesar $40 \%$ untuk siklus 
1, dan $60 \%$ untuk siklus 2. 2). Meningkatnya keterampilan proses sebesar $20 \%$ pada setiap siklus.

Analisi data yang digunakan dalam penelitian ini yaitu menggunakan analisis diskriptif komparatif dengan membandingkan hasil belajar dari kondisi awal dan setiap siklus pembelajaran. Analisis data kualitatif merupakan hasil pengamatan yang menggunakan analisis diskriptif kualitatif. Selanjutnya dilakukan komparasi data setiap siklus untuk memastikan adanya peningkatan keterampilan proses dan hasil belajar siswa.

\section{HASIL DAN PEMBAHASAN}

Setelah melakukan analisa terhadap data yang diperoleh dari dua siklus yang dilaksanakan, maka dapat disimpulkan bahwa penggunaan model pembelajaran SAVI pada subtema tugasku sehari-hari di rumah menunjukkan peningkatan Keterampilan proses dan hasil belajar siswa. Tabel 1 merangkum komparasi tingkat Keterampilan Proses kondisi awal, siklus 1 sampai siklus 2.

\section{Tabel 1 komparasi tingkat keterampilan proses}

\begin{tabular}{|l|c|c|}
\hline \multirow{2}{*}{\multicolumn{1}{|c|}{ Pembelajaran }} & \multicolumn{2}{c|}{ TingkatKeterampilan Proses } \\
\cline { 2 - 3 } & Mean & \% Kenaikan \\
\hline Kondisi Awal & 11,50 & - \\
\hline Siklus 1 & 14,14 & $22,96 \%$ \\
\hline Siklus 2 & 17,14 & $21,22 \%$ \\
\hline
\end{tabular}

Dari Tabel 1 diatas, diperoleh temuan: a) pada kondisi awal, rata-rata tingkat keterampilan proses dalam pembelajaran baru mencapai 11,50 ; b) pada siklus 1 rata-rata tingkat keterampilan proses dalam pembelajaran mencapai 14,14 ; c) pada siklus 2 rata-rata tingkat keterampilan proses dalam pem-belajaran mencapai 17,14. Capaian ini menunjukkan peningkatan keterampilan proses sebesar 22,96\% pada siklus 1 , dan $21,22 \%$ pada siklus 2.

Kenaikan mean hasil belajar dan persentase jumlah ketuntasan bela- jar siswa pada muatan Bahasa Indonesia dan Matematika dirangkum dalam Gambar 1. Dari Gambar 1 diperoleh data berikut: 1) muatan Bahasa Indonesia diperoleh: a) pada kondisi awal, mean hasil belajar baru 58, sedangkan persentase jumlah siswa yang mencapai KKM hanya 31,82\% (7 siswa); b) pada siklus 1 , mean hasil belajar menjadi 60,32 dan persentase meningkat menjadi 50\% (11 siswa); c) pada siklus 2, mean hasil belajar meningkat menjadi 76,14 dan persentase jumlah siswa yang mencapai KKM meningkat menjadi 86,63\% (19 siswa). 
Peningkatan Keterampilan Proses dan Hasil Belajar Subtema Tugasku Sehari-hari di Rumah (Eka Ning Tyas)

2) muatan Matematika diperoleh: a) pada kondisi awal, mean hasil belajar baru 53, sedangkan persentase jumlah siswa yang mencapai KKM hanya $27,27 \%$ (6 siswa); b) pada siklus 1 , mean hasil belajar menjadi 59.09 dan persentase meningkat menjadi $45,45 \%$ (10 siswa); c) pada siklus 2 , mean hasil belajar meningkat menjadi 72,5 dan persentase jumlah siswa yang mencapai KKM meningkat menjadi $81,82 \%$ (18 siswa).

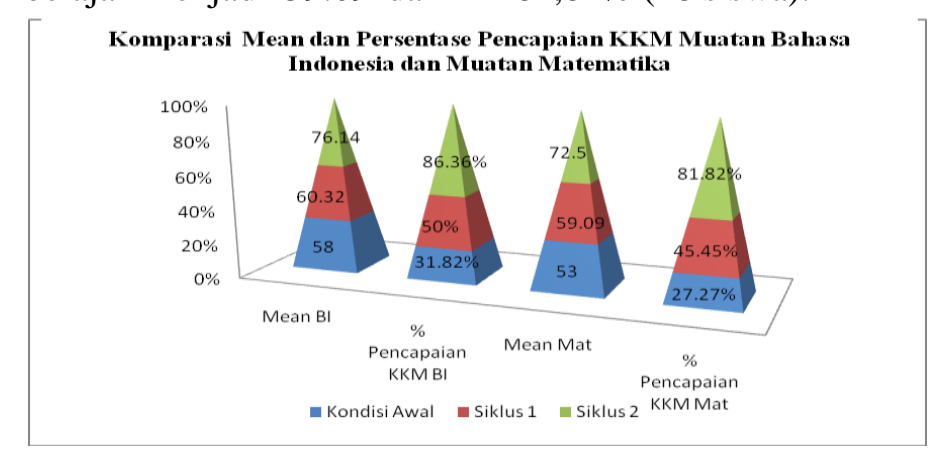

\section{Gambar 1 Komparasi Mean dan Ketuntasan Belajar Siswa}

Temuan ini sejalan dengan

\section{Keberhasilan model SAVI dalam} meningkatkan keterampilan proses

Data pada tabel keterampilan proses pembelajran kondisi awal, siklus 1 dan siklus 2 menunjukkan temuan rerata keterampilan proses pemecahan masalah matematika pada kondisi awal 11,50 pada siklus 114,14 dan siklus 2 17,14. Temuan ini mengindikasikan adanya peningkatan tingkat keterampilan proses pembelajaran. Besaran peningkatan $22,96 \%$ pada siklus 1 dan $21,22 \%$ pada siklus 2 . Jika dibandingkan dengan indikator kinerja $20 \%$ ternyata temuan siklus 1 dan 2 tersebut telah mencapai keberhasilan.

Keberhasilan penelitian ini menunjukkan bahwa siswa mampu mengamati, menanya, mencoba, mengumpulkan informasi, mengasosiasi, dan mengkomunikasikan. penelitian Kusumawati Sri Wahyuni (2013), Suswadi (2010) dan Krisnawati, Ony (2011).

\section{Keberhasilan model SAVI dalam meningkatkan hasil belajar siswa \\ Data pada grafik 1 hasil belajar} siswa pada muatan Bahasa Indonesia dan muatan Matematika kondisi awal, siklus 1 dan siklus 2 menunjukkan temuan 1) muatan Bahasa Indonesia, kondisi awal, mean 58, pada siklus 1 mean 60,32 pada siklus 2 mean 76,14. 2) muatan Matematika, kondisi awal, mean 53, pada siklus 1 mean 59,09 pada siklus 2 mean 72,5. Temuan ini mengindikasikan adanya peningkatan hasil belajar siswa yang telah mencapai KKM. Besaran peningkatan muatan Bahasa Indonesia pada kondisi awal 31,82\% (7 Siswa), menjadi 50\% (11 Siswa) pada siklus 1 dan $86,63 \%$ (19 
Siswa ) pada siklus 2. Sedangkan besaran peningkatan muatan matematika pada kondisi awal hanya $27,27 \%$ (6 Siswa), menjadi 45,45\% (10 Siswa) pada siklus 1 , dan pada siklus 2 meningkat menjadi $81,82 \%$ (18 Siswa). Jika dibandingkan dengan indikator kinerja $40 \%$ untuk siklus $1,60 \%$ untuk siklus 2 ternyata temuan siklus 1 dan 2 tersebut telah mencapai keberhasilan.

Temuan ini sejalan dengan penelitian Suswadi (2010), Silvianawati Purwanti (2012), Krisnawati, Ony (2011).

\section{SIMPULAN DAN SARAN SIMPULAN}

Berdasarkan hasil penelitian dan pembahasan, dapat disimpulkan bahwa Model Pembelajaran SAVI:

1. Meningkakan keterampilan proses pembelajaran siswa kelas II SD Negeri 1 Bolo, Kecamatan Wonosegoro, Kabupaten Boyolali sebesar $22,96 \%$ pada siklus 1 dan pada siklus 2 sebesar $21,22 \%$.

2. Meningkatkan hasil belajar siswa yang telah mencapai KKM pada muatan Bahasa Indonesia dari kondisi awal yang hanya $31,82 \%$

\section{DAFTAR PUSTAKA}

(7 Siswa), meningkat menjadi 50\% (11 Siswa), pada siklus 1 dan siklus 2 meningkat menjadi

86,36\% (19 Siswa). Dan hasil belajar pencapaian KKM muatan Matematika pada kondisi awal 27,27\% ( 6 Siswa), pada siklus 1 meningkat menjadi 45,45\% ( 10 Siswa), dan meningkat menjadi $81,82 \%$ (18 Siswa) pada siklus 2 .

\section{Saran}

Saran yang diajukan dalam penelitian ini adalah, para guru hendaknya: 1) berusaha mengaktifkan siswa dalam proses pembelajaran, 2) Penerapan model pembelajaran SAVI pada sub tema tugasku sehari-hari di rumah seperti diuraikan di atas, hendakanya dijadikan salah satu alternatif untuk meningkatkan hasil belajar siswa dari kelas I sampai dengan kelas VI Sekolah Dasar, 3) Untuk meningkatkan profesionalisme, seorang guru hendaknya berusaha untuk selalu meningkatkan dan memperbaiki proses pembelajara

Depdiknas. (2013). Lampiran Permendiknas Nomer 65 Tahun 2013 tentang standar proses pendidikan dasar dan menengah. Jakarta : depdiknas.

Dimyati dan Mujiono. (2009). Belajar dan Pembelajaran. Jakarta : PT Rineka Cipta.

Hosnan. (2014). Pendekatan saintifik dan konteks tual dalam pembelajaran abad 21. Bogor: Ghalia Indonesia. 
Peningkatan Keterampilan Proses dan Hasil Belajar Subtema Tugasku Sehari-hari di Rumah (Eka Ning Tyas)

Kemendikbud. (2014). Materi pelatihan implementasi kurikulum 2013. Jakarta : Badan Pengembangan Sumberdaya Manusia pendidikan dan kebudayaan dan penjamin mutu pendidikan kementrian pendidikan dan kebudayaan.

Kusumawati Sri Wahyuni (2013). Penerapan model pembelajaran SAVI untuk meningkatkan keterampilan pemecahan masalah di Sekolah Dasar. Skripsi Universitas Negeri Surabaya Tidak diterbitkan.

Krisnawati, Ony, (2011). Penerapan model SAVI dapat mengubah miskonsepsi siswa, meningkatkan aktivitas dan hasil belajar siswa dalam pembelajaran Pada siswa kelas IV SDN Talangagung 01 Kecamatan Panjen Kabupaten Malang. Skripsi Universitas Negeri Surabaya. Tidak diterbitkan.

Meier, Dave. (2002). The Accelerated Learning Handbook. Bandung : MMU (Mizan Media Utama).

Meier, Dave. 2005. The Accelerated Learning Handbook: Panduan Kreatif dan Efektif Merancang Program Pendidikan dan Pelatihan. Diterjemahkan Oleh Rahmani Astuti. Bandung : Kaifa.

Meier, Dave. (2005). Kelemahan dan kelebihan pendekatan SAVI.[Online]. Tersedia : http://goez17.wordpress.com. (8 Oktober 2014).

Silvianawati Purwanti, (2011). pengaruh penerapan pembelajaran tematik kelas II SD dengan menggunakan model pembelajaran SAVI terhadap belajar siswa SD Negeri Mangunsari 04 Salatiga semester 2 tahun 2010/2011. Skripsi UKSW Salatiga. Tidak diterbitkan.

Sudjana, Nana. (2010). Penilaian hasil proses belajar mengajar. Bandung : PT. Ramaja Rosdakarya.

Suswadi, (2010). Peningkatan keterampilan membaca pemahaman dengan pendekatan SAVI pada siswa kelas VI SDN Kutawaru 04 Kecamatan Cilacap tengah Kabupaten Cilacap. Jurnal Humanoria, Portal (11):19-28.

Wahid Murni, Arrifin mustikawan, dan Ali Ridho. (2010). Evaluasi pembelajaran : kompetensi dan peaktik. Yogyakarta : Nuha Letera.

Wahyudi Johar, Primiani Cicilia Novi, Wahyuni Yayuk, (2011). Peningkatan kemampuan berfikir tingkat tinggi pada mata pelajaran Biologi melalui model SAVI. Jurnal Pendidikan, portal (3):21-32

Warta (2010). Penmaaman Siswa kelas 3 MI Cipeundeuy kecamatan jati nunggal kabupaten sumedang terhadap materi membandingkan pecahan sederhana. Skripsi PGSD UPI Kampus Sumedang : Tidak diterbitkan. 